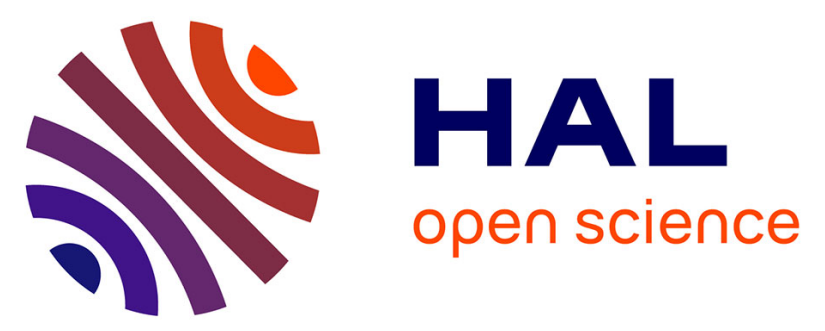

\title{
Working in large food retailers in France and the USA: The key role of institutions
}

\author{
Philippe Askenazy, Jean-Baptiste Berry, Françoise Carré, Sophie
}

Prunier-Poulmaire, Chris Tilly

\section{To cite this version:}

Philippe Askenazy, Jean-Baptiste Berry, Françoise Carré, Sophie Prunier-Poulmaire, Chris Tilly. Working in large food retailers in France and the USA: The key role of institutions. Work, Employment and Society, 2012, pp.588-605. hal-01058686

\section{HAL Id: hal-01058686}

\section{https://hal-univ-paris8.archives-ouvertes.fr/hal-01058686}

Submitted on 21 Nov 2017

HAL is a multi-disciplinary open access archive for the deposit and dissemination of scientific research documents, whether they are published or not. The documents may come from teaching and research institutions in France or abroad, or from public or private research centers.
L'archive ouverte pluridisciplinaire HAL, est destinée au dépôt et à la diffusion de documents scientifiques de niveau recherche, publiés ou non, émanant des établissements d'enseignement et de recherche français ou étrangers, des laboratoires publics ou privés. 


\section{WORKING IN LARGE FOOD RETAILERS IN FRANCE AND THE USA: THE KEY ROLE OF INSTITUTIONS}

Par Philippe Askenazy, Jean-Baptiste Berry, Françoise Carré, Sophie Prunier-Poulmaire, Chris Tilly.

\section{Introduction}

A persistent theme in international research on employment practices has been the continuing divergence of management practices across nations despite the growth of globalizing forces (Gallie, 2007; Hall and Soskice, 2001; Katz and Darbishire, 2000; Whitley, 1999). This divergence has resulted in distinct outcomes for jobs with clear differences in average job quality across countries. Thus, questions about the nature of societal institutions' effects on business practices, particularly as they relate to employment, persist. They remain a fruitful area for research because of what they can teach us about the dynamics of industrial societies and also because of implications that can be drawn for employment and social policies.

Following recent research (Colling and Clark, 2002; Royle, 2006), the present article employs a sectorbased approach to examine the interrelationships of markets, technology, work organization and societal institutions. This article explores these questions in the retail sector, the largest employment sector in the developed world and one with a track record of offering low quality jobs (Carré et al., 2010). The analysis, motivated by an interest in job quality outcomes in entry level jobs, asks what accounts for key differences in average job quality for cashier jobs in French and US supermarkets. The starting point is a set of cross-national differences in compensation, productivity and physical aspects of the job.

Explaining cross-national differences in job characteristics

Two bodies of literature about the determinants of job quality are particularly relevant for analysing mechanisms that might account for job divergences. A first literature studies the practices of multinationals outside their home country, in order to assess the impact and interplay of multinational home country 'dominance' effects (that is, the effect of dominant firm practices and their dissemination of certain national norms regarding employment) and 'societal' effects generated by host country institutions ('national' effects) on management practices and employment systems (Ferner, 1997; Meardi et al., 2009; Royle, 2006; Smith and Meiksins, 1995). This literature's primary focus and point of entry are managerial practices, where such influences are felt, and which in turn help determine job characteristics. 
A second group of analyses starts from observed differences in average job quality and analyses the contribution of societal institutions to these differences using sector-specific cross-national comparisons. Authors use selected job characteristics as the point of entry for comparing systems of employment. Starting from a micro-level analysis, they move up to locate jobs within systems of employment and the latter within a constellation of interacting social and economic spheres. For example, Baret et al. (2000) examine working time in retail in three European countries and Japan, while Bosch and Lehndorff (2005) analyse multiple service industries (including retail) in 10 European countries. This scholarship draws upon concepts initially developed by Maurice et al. (1986) to provide analytically meaningful categories for cross-national comparison of work and employment systems. Bosch and Lehndorff (2005) summarize four main spheres of influence on work: ${ }^{1}$

Product market and consumers, including parameters of competition and product market regulation; Management strategies, including corporate governance and technology;

The labour market and associated institutions and norms, public policy, customers and industrial relations;

The welfare state and gender relations including family structures and taxes and benefits. ${ }^{2}$

Both literatures approach these issues through sector-specific studies, thus setting sectoral characteristics regarding market, production technology and the organization of work as mediating processes for economic forces and societal effects. For example, Colling and Clark (2002) argue that sector effects, growing out of a company's particular sector of production - and its shared practices mediate in important ways the dominance effects of a multinational's home country, enhancing or weakening host country effects. And within Gadrey's (2000) framework, market and organizational structures will differ systematically by sector. Dialogue bridging the two literatures has been limited, but appears potentially fruitful.

The present work resonates with both literatures in recognizing the role of sector characteristics in mediating the effects of broader market and societal forces. It is posited that national business systems (Whitley, 1999) which form home country effects abroad will be expressed differently by sector despite some common features, and that sector patterns, again despite certain universal features, will take different shapes in different nations. Thus, this article develops the notion of a national-sectoral model that combines societal and sectoral effects.

To examine these effects, the current article presents comparative sector studies of food retail in France and the USA. Comparison and analytical leverage are facilitated by focusing on a single job, that of the cashier. This job is a natural choice, both because it is the largest category in the sector and because of widespread concern about the quality of entry level jobs in retail. The focus on cashiers also has gendered import, since the job is disproportionately female. The study also reduces confounding sources of variation by limiting attention to food retail, the largest sub-sectoral category.

Though this study's framework connects both to the 'dominant firms' literature and to the 'spheres of influence' literature, the approach is distinct from both. As distinct from the dominant firm research, which tends to examine multinationals in varied national settings, this study compares employment practices in retail across several large companies, multinational and otherwise, in two national settings. The settings, the USA and France, are the home countries of the two largest retail multinationals, Wal-Mart and Carrefour. However, the focus is not on these two dominant firms per se but rather on identifying characteristics of the two national-sectoral models that constitute the 
home contexts for these firms (and, due to confidentiality agreements, it is not possible to identify participating companies). The other distinction with the dominant firms literature is that job characteristics are taken as the analytical starting point, rather than management strategies per se.

The 'spheres' literature embodies a number of approaches to assessing the influence of sectoral and societal influences. Baret (2000), in a case study of food retail in France, examines the interaction of management strategies with collective bargaining and regulatory restrictions on working time, but does not consider the institutions and norms regulating the division of labour within the family, and thus labour supply. Jany-Catrice and Lehndorff (2005), studying retail in 10 countries, essentially limit their attention to management strategies and labour supply. Gadrey et al. (2000), summing up Baret's and three other national case studies of retail, adopt a broader frame that includes both sets of institutions as well as management strategies in explaining working time outcomes. The present article broadens the field of view still further, including a wider set of job outcomes and societal effects, including product market regulation. This wider window on retail jobs reflects (but does not test) a perspective in which sets of employment practices tend to fit together into a mutually sustaining or at least compatible package. It is accomplished by centering the comparison on two countries and focusing on a particular sub-sector and job.

\section{Methods}

In addition to drawing on national statistics, this article brings a unique set of case studies to bear on this comparison. Based on a common methodology used for a cross-national research project on low wage work in the USA and five European countries, the case studies conducted by teams between 2005 and 2007 provide a broadly representative sample of large stores within large retail food companies (with the exception of hard discounters): six outlets of five major national chains in France and 12 stores at 10 chains in the USA from various regions. ${ }^{3}$ Interviews were conducted confidentially and work activity was observed. The interview topics covered work organization, workplace relations, recruitment and training policies as well as compensation issues. Confidential worker interviews detailed schedules, training and working conditions. Workers could refuse to participate, but very few did because the interview time was paid time as part of the work shift.

In France, chains in the study ranged from super-discount stores to high end stores, with no hard discounters included. For each participating group and chain, national or international HRMs (human resource managers) or SRMs (social relation managers) were interviewed. For each outlet, the methodology entailed face-to-face interviews with a national union representative, store directors, store HRM if any, schedules planner, cashier supervisor, about half of the other store managers, one or two workers' representatives at the establishment level if any and the occupational practitioners. In supermarkets, five cashiers were interviewed; in hypermarkets, 15 to 20 cashiers were interviewed. The main negotiator of the French Employers' Organization of Large Food Retailers and two union negotiators for national sectoral agreements were also interviewed. A total of 106 interviews were conducted.

In the USA, participating retailers included three higher service, one medium service, three warehouse formats and three 'tiered' service (meaning that stores have areas providing higher end services while the rest of the store provides a medium level of service) companies. In total, 113 interviews were conducted. Of these, 47 were with frontline workers including cashiers and clerks, and 13 were with first level supervisors. The remainder were with all levels of corporate, regional and store level management in operations and human resources. Interviews were conducted with union representatives at two of three companies that had unions. 


\section{Explaining differences in pay, productivity and posture}

Table 1, panel 1 compares absolute hourly pay levels between the two countries. Using a purchasing power parity (PPP) conversion allows comparison of standards of living. By this standard, in the aggregate, workers in large French food outlets were better paid than their US counterparts, but French cashiers in particular earned slightly less on average (though more in the study field cases). However, from the viewpoint of transnational corporations able to convert currencies and make global location choices, a nominal exchange rate conversion was more relevant; by this criterion, French workers were on average more expensive. Moreover, the desirability of the cashier job within a country depended primarily on the relative level of pay, in comparison with other alternatives. Using two-thirds of the median hourly wage in each country as a cut-off point for low wages, French retail workers were far more likely to be well paid in relative terms (Table 1, panel 2).

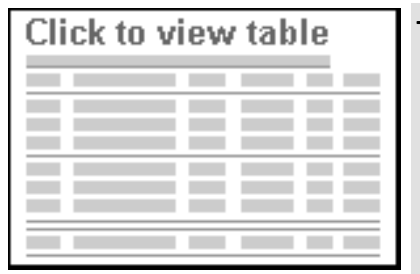

Table 1. Profile of French and US retail

Table 1. Profile of French and US retail

\begin{tabular}{|c|c|c|c|}
\hline \multicolumn{4}{|c|}{ Gross hourly wages of recail workers in France and the USA } \\
\hline & \multicolumn{2}{|c|}{ France 2006 (in 2007 US\$) } & \multirow[t]{2}{*}{ USA 2007} \\
\hline & Pppi & Nomind exchange rate & \\
\hline All retal & $\$ 13.58$ & $\$ 16.91$ & $\$ 14.85$ \\
\hline $\begin{array}{l}\text { Large food stores } \\
\text { (supermarket or larger) }\end{array}$ & $\$ 13.25$ & $\$ 16.49$ & $\$ 12.31$ \\
\hline Cashiers in large food stores & $\$ 11.56$ & $\$ 14.39$ & $\$ 12.16$ \\
\hline Cathiers from cases & $\$ 9.25-\$ 12.02$ & $\$ 11.51-\$ 14.96$ & $\begin{array}{l}\text { Seart at \$5.15-10. } \\
\text { top } \$ 7-\$ 20.83\end{array}$ \\
\hline \multicolumn{4}{|c|}{ Percentage of workers falling below low hourly wage' threshold in France and the USA 2003} \\
\hline & France 2003 & & USA 2003 \\
\hline All retail & $18 \%$ & & $37 \%$ \\
\hline Food reeail & $19 \%$ & & $48 \%$ \\
\hline Cashiers in reaail & $29 \%$ & & $70 \%$ \\
\hline Cashiers in food recail & $30 \%$ & & $6 \%$ \\
\hline \multicolumn{4}{|c|}{ Reeail productivity measures for France and the US PPP } \\
\hline & France & & US \\
\hline $\begin{array}{l}\text { Annual sales per square foot of } \\
\text { selling area (large food stores) }\end{array}$ & $\$ 1348(2007)$ & & $\$ \$ 82(2007)$ \\
\hline $\begin{array}{l}\text { Annual sales per hour (large } \\
\text { food stores) }\end{array}$ & $\$[260-290](2007)$ & & $\$ 139(2007)$ \\
\hline $\begin{array}{l}\text { Value added per employee- } \\
\text { hour (all recail) }\end{array}$ & $\$ 29.33(2005)$ & & $\$ 26.25(2005)$ \\
\hline $\begin{array}{l}\text { Typical targets for items } \\
\text { scanned per minute by cashiers }\end{array}$ & 25 (up to 30 ) & & 20 (up to 25) \\
\hline \multicolumn{4}{|c|}{ 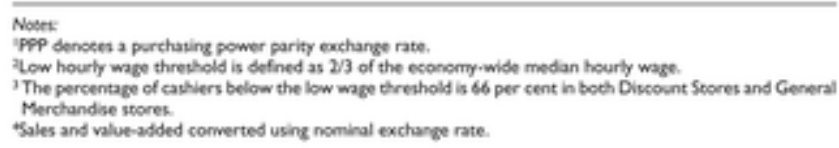 } \\
\hline \multicolumn{4}{|c|}{ 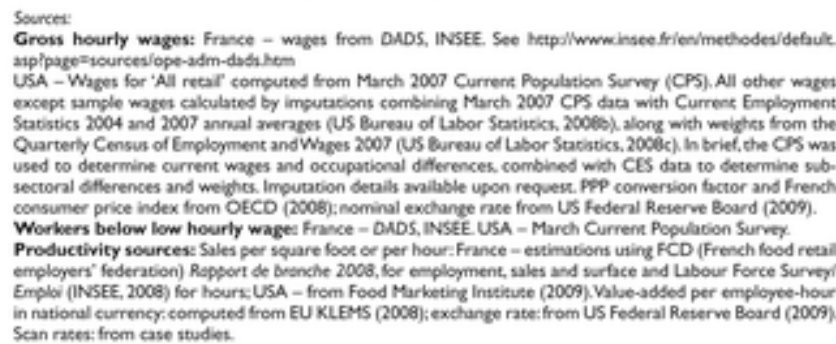 } \\
\hline
\end{tabular}

Notes: 
PPP denotes a purchasing power parity exchange rate.

2

Low hourly wage threshold is defined as $2 / 3$ of the economy-wide median hourly wage.

3

The percentage of cashiers below the low wage threshold is 66 per cent in both Discount Stores and General Merchandise stores.

4

Sales and value-added converted using nominal exchange rate.

Sources:

Gross hourly wages: France - wages from DADS, INSEE. See

http://www.insee.fr/en/methodes/default.asp?page=sources/ope-adm-dads.htm

USA - Wages for 'All retail' computed from March 2007 Current Population Survey (CPS). All other wages except sample wages calculated by imputations combining March 2007 CPS data with Current Employment Statistics 2004 and 2007 annual averages (US Bureau of Labor Statistics, 2008b), along with weights from the Quarterly Census of Employment and Wages 2007 (US Bureau of Labor Statistics, 2008c). In brief, the CPS was used to determine current wages and occupational differences, combined with CES data to determine sub-sectoral differences and weights. Imputation details available upon request. PPP conversion factor and French consumer price index from OECD (2008); nominal exchange rate from US Federal Reserve Board (2009).

Workers below low hourly wage: France - DADS, INSEE. USA - March Current Population Survey.

Productivity sources: Sales per square foot or per hour: France - estimations using FCD (French food retail employers' federation) Rapport de branche 2008, for employment, sales and surface and Labour Force Survey/Emploi (INSEE, 2008) for hours; USA - from Food Marketing Institute (2009). Value-added per employee-hour in national currency: computed from EU KLEMS (2008); exchange rate: from US Federal Reserve Board (2009). Scan rates: from case studies.

\section{View larger version}

Note that higher hourly pay in France does not necessarily imply adequate pay, both because of the higher French cost of living and because of the part-time employment that is common in retail in both countries.

A second striking difference concerns productivity performance (Table 1, panel 3). Sales per square foot of selling area were, remarkably, nearly three times as high in large French retail establishments, denoting much more intensive use of space. Value-added per employee-hour was almost 12 per cent greater in French retail. Zooming in on target item scanning rates, a key measure of cashier productivity in both countries, also revealed a higher rate in France. This higher productivity makes higher compensation economically sustainable for firms.

A third difference, not shown in the Table, was that French cashiers sit whereas US cashiers stand.

Contrasts in job characteristics not accounted for by market and organizational differences

One possible source of difference in jobs was the national mix of food store formats. Perhaps a greater role for large stores in France generated higher pay and productivity. This analysis omits 
convenience and 'mom and pop' stores but even within large food stores, various formats coexist in both countries.

Category definitions differ across countries, making a head-to-head comparison difficult. Nonetheless, Table 2 reveals broad similarities in store formats. In both countries, large outlets dominate food sales but in fact this dominance was somewhat more pronounced in the USA. The larger share of hypermarkets in France than of supercenters and warehouse stores in the USA was primarily an artefact of a lower selling area threshold for the French category. (Hypermarkets are defined as stores over $2500 \mathrm{~m}^{2}$; therefore the French hypermarket category includes stores that would be classified as supermarkets in the USA.) The much greater floor area of US supercenters compared to French hypermarkets stems in part from this definitional difference, but also presumably reflects the more recent rollout of supercenters and hypermarkets in the USA and the well known lower density typical of US development. France has a larger overall average store size, but the difference is small. Given similar store areas and France's greater sales per square foot (Table 1 , panel 3), average sales per store were considerably higher in France.

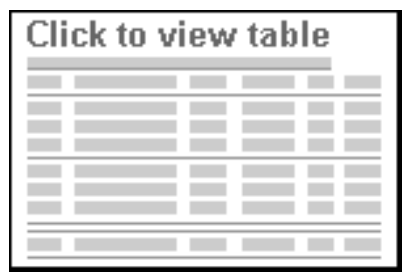

Table 2. Profile of large food stores in France and the USA

Table 2. Profile of large food stores in France and the USA

Table 2. Profile of large food stores in France and the USA

\begin{tabular}{llcl}
\hline & France 2007 & USA 2002 & USA 2006 (imputed) \\
\hline \% of total food sales & & & \\
$\quad$ Supermarkets & $33.1 \%$ & $66.4 \%$ & $65.4 \%$ \\
Hypermarkets/supercenters & $33.0 \%$ & $15.1 \%$ & $20.3 \%$ \\
$\quad$ All large food retailers & $66.1 \%$ & $81.5 \%$ & $85.8 \%$ \\
Average square feet per store, 1000s & & & \\
$\quad$ Supermarkets & 11.7 & 11.8 & - \\
Hypermarkets/supercenters & 61.0 & 123.9 & - \\
$\quad$ All large food retailers & 18.9 & 16.5 & - \\
Average annual sales per store, US $\$ 1000$ & & & \\
$\quad$ Supermarkets & $\$ 12,239$ & $\$ 5975$ & $\$ 6471$ \\
Hypermarkets/supercenters & $\$ 102,648$ & $\$ 65,677$ & $\$ 71,114$ \\
All large food retailers & $\$ 25,482$ & $\$ 8492$ & $\$ 10,135$ \\
\hline
\end{tabular}

Notes:

French figures from 2007, US figures from 2002 (most recent Economic Census). For USA, 'Hypermarkets/ supercenters' corresponds to the 'Warehouse stores and supercenters' category. French sales converted to dollars using nominal exchange rates.

Imputation procedures for USA 2006: percentage of food sales based on sales $i_{2} 006=$ sales $_{i 2002}$ *

(establishments ${ }_{2006} /$ establishments, 2002 ), where i denotes a size category, 2006 count of establishments from County Business Patterns (US Census Bureau, 2008a).

Average annual sales per store: store sales $i_{i, 2006}=$ store sales $_{i, 2002} *$ (total sales $i, 2006 /$ total sales $i, 2002$ ) / (establishments ${ }_{2006} /$ establishments ${ }_{i, 2002}$ ), with total sales for the sub-sector from Annual Retail Survey (US Census Bureau, 2008b).

Sources:

France - FCD (French food retail employers' federation) Rapport de branche (FCD, 2008) or INSEE Compte du commerce 2008 (INSEE, 2009b). USA - All from US Economic Census 2002: sales from US Census Bureau (2005a); area from US Census Bureau (2005b).

Notes: 
French figures from 2007, US figures from 2002 (most recent Economic Census). For USA, 'Hypermarkets/supercenters' corresponds to the 'Warehouse stores and supercenters' category. French sales converted to dollars using nominal exchange rates.

Imputation procedures for USA 2006: percentage of food sales based on sales ${ }_{i, 2006}=$ sales $_{i, 2002}$ * (establishments ${ }_{i, 2006}$ / establishments ${ }_{i, 2002}$ ), where i denotes a size category. 2006 count of establishments from County Business Patterns (US Census Bureau, 2008a).

Average annual sales per store: store sales ${ }_{i, 2006}=$ store sales $_{i, 2002}$ * (total sales ${ }_{i, 2006} /$ total sales ${ }_{i, 2002}$ ) / (establishments ${ }_{i, 2006}$ / establishments ${ }_{i, 2002}$ ), with total sales for the sub-sector from Annual Retail Survey (US Census Bureau, 2008b).

\section{Sources:}

France - FCD (French food retail employers' federation) Rapport de branche (FCD, 2008) or INSEE Compte du commerce 2008 (INSEE, 2009b). USA - All from US Economic Census 2002: sales from US Census Bureau (2005a); area from US Census Bureau (2005b).

\section{View larger version}

In brief, there was little to indicate that larger food stores in France explained differences in pay and productivity. An explanation of the differences found in pay, pace and physical position of cashier jobs must be found elsewhere.

The mix of tasks bundled into cashier jobs was, for the most part, identical across the Atlantic. The French 'SBAM' (smile, hello, good-bye, thank-you) would be recognizable to any US shopper. However, there were several noteworthy differences. US cashiers almost invariably identified and weighed produce, whereas in France consumers were responsible for these tasks in many settings. French cashiers removed anti-theft tags from liquor and clothing, whereas in the USA such tags were rare in the typical grocery order. US cashiers usually bagged groceries or at least assisted the bagger and customer with bagging; in France the customer was expected to bag. According to the researchers' ergonomic observations, French cashiers typically did more to monitor for theft, including checking overhead mirrors and a panoramic lens at cash register level, checking goods on the belt (e.g. examining multi-packs of bottles for hidden small items) and checking inside customers' bags. French cashiers counted their cash at the end of a shift or when unloading a full register; in the USA, supervisors counted cash.

The fact that US cashiers stand was connected to bagging. A human resource executive in a US supermarket chain explained: 'If you're sitting, it would be hard to swivel around and stand to bag. So that would be the most important reason that US cashiers stand.' Interestingly, the ergonomic literature shows that both models - exclusively upright and exclusively seated postures - have negative health consequences. Ideally, workstations should accommodate both positions (Lehman et al., 2001). This literature also shows that productivity and satisfaction are not significantly different in the two positions. So standing versus sitting cannot explain differences in productivity and pay between the two countries.

Bagging by US cashiers did not explain the difference in scan rates, which were calculated only for times when the register was online. A US warehouse store cashier noted, 'Like if you're scanning things, you can hit "total" between items and it'll stop the count.' At first glance, US cashiers' task of recognizing and weighing produce seemed a possible explanation for slower target scan rates but this explanation is unsatisfactory. Field work confirmed that very high scan rate objectives were also found in French hypermarkets, where cashiers were expected to weigh produce. In fact, given French 
cashiers' expanded responsibilities for anti-theft monitoring, one might expect them to scan more slowly. A last source of productivity disparity could be the scan technology but there was no evidence that French retailers used more advanced technology.

Relatively small differences in the tasks of cashiers in France and the US were consistent with the clear divergence between sitting and standing. But they did not explain the rather large differences in pay and productivity between the two settings.

Societal effects with direct impacts: labour regulation

Both countries exhibited direct institutional effects in the labour regulation sphere, meaning institutional features impacted on job quality directly rather than, for example, via changing the decision terms of firms or employees. Contrasts in labour regulation played the most direct role in this two-country comparison, as also noted by others (Gadrey, 2000).

First and foremost, the sharp difference between the high value of the minimum wage in France and the low US minimum wage played a key role in the stark contrast in incidence of low wage work in retail. In France a high national minimum wage (SMIC) relative to the national median wage contributed to the lowest incidence of low wages in retail of six countries in a cross-national study (Carré et al., 2010). In 2006, the French minimum wage stood at 68 per cent of the median wage. With a definition of low wage workers as earners of less than two-thirds of the median net hourly wage of full-time staff, this rate virtually drove the proportion of low wage workers to 0 per cent. It has since lost ground.

The US minimum wage has lost real value over the past 30 years, under intensive lobbying by industries employing low wage workers, particularly retail and food service. By early 2007, the real minimum wage had declined to only 30 per cent of the median wage. ${ }^{4}$ The US Congress implemented a relatively small increase in 2007, with increments in 2008 and 2009. States may set a minimum above the federal level and in 200730 out of 50 did (US Department of Labor, 2008). Where implemented, state minimum wages are about 20 per cent higher than the federal one (Dube et al., 2010).

The minimum wage affects both entry level wages and the reservation wage. In both countries, food retailers set entry level pay at or slightly above the minimum wage. Using the nominal value of the US minimum wage implemented in July 2008 (\$6.55) as a yardstick, one in 12 US retail workers - and one in five part-time, frontline retail workers - fell below the benchmark in early 2007, while only one in 19 private sector workers fell short (Carré and Tilly, 2008). Furthermore, the minimum wage's high relative value in France, combined with the RMI (guaranteed minimum income), contributed to a higher reservation wage economy-wide.

Second, the USA's lack of mandated hourly pay and benefit parity between full-time and part-time workers contributed to the high incidence of low wage work in US retail relative to France. In the USA, part-time work was a primary means of establishing a lower pay scale and excluding workers from employer-sponsored benefit plans. The contrast in pay alone was clear. In 2007, part-timers in retail earned 67 per cent of full-timers' hourly wages (and 31\% of full-time weekly earnings), a disadvantage markedly exceeding that of part-timers economy-wide (77\% of full-time wages) (Carré and Tilly, 2008). Benefit exclusion was a liability, as a supermarket cashier noted: 'Some people, they work over 32 hours but they're just not considered full-time. And that makes them so mad.'

Third, unions' position in the labour relations system differed between the two countries. In France, collective bargaining influenced retail wages through sectoral agreements with major chains that 
were extended to cover almost all workers. However, actual union membership was low - around 2 per cent - and union power in stores was weak. A hypermarket cashier's perspective was typical: 'Few people join unions, because of fear ... Fear of losing your job takes people's spirit and consciousness away.' While the bargained starting wage was regularly set below the SMIC, the agreement included seniority bonuses. In large incorporated chains, unions were able to secure additional advantages including profit-sharing schemes. Consequently, in such chains, cashiers with one year's seniority could earn up to 125 per cent of the hourly SMIC. US retail unions had higher membership density - 19 per cent in grocery - but paradoxically, less power. They did bargain for higher benefits and more predictable work schedules at unionized stores, but had little impact on compensations sector-wide.

Societal effects with indirect impacts: product market regulation

Differences in the two national-sectoral models arising from contrasts in the regulation of shopping itself, part of the product market sphere, exerted indirect effects on cashier job outcomes. French store opening hours, shopping cultures and anti-competitive regulations induced concentrated peak hours, with (exceedingly) high customer flows and consequent pressures for cashiers. In contrast, US customer-oriented regulations led to the provision of relatively more services and greater job burdens, but in this case for shelf-stackers, who individually labelled items as mandated by consumer protection laws, rather than cashiers.

US food retail workers frequently worked one weekend day and evening schedules. In the near absence of regulations, large stores were open seven days a week and at least 15 hours daily with a trend to 24-hour operation. The impact on workers was clear, as a full-time supermarket cashier supervisor noted: 'My shift starts at two in the afternoon and doesn't end until eleven at night ... You have to be able to be flexible with your hours ... You don't have a set schedule a week ... Sometimes I'll get a Saturday off, sometimes I'll get a Sunday off.' In contrast, French food store hours were restricted by regulations and custom. French supermarkets were typically open from 9 a.m. to 8 p.m. and hypermarkets closed at 10 p.m.; both could open five Sundays a year, with additional exceptions for tourist zones and, since August 2009, for some retail zones facing extreme customer flows. In central business districts, or in tourist zones, stores could remain open 16 hours a day. Despite a slight increasing trend, approximately one hour over a decade, shopping hours were concentrated. Still, even with these restrictions, retail workers frequently experienced shift work because of set-up time and clean-up tasks under European Union food safety requirements.

In the two countries, store hours also reflected social schedules and rhythms of family life which in turn strongly shaped contrasting shopping behaviours. French customers carried out only marginal purchases after dinner time (7-9 p.m.), except for shift workers. Peak shopping hours were concentrated on Monday-Friday 5-8 p.m. and on Saturdays, largely as a result of the limit on Sunday opening. This limit constrained peak hours to about 20-25 hours per week (three hours MondayFriday, plus five to 10 hours on Saturday), whereas US stores typically had about 36 peak hours (four hours on weekdays and eight hours on each weekend day).

Moreover, France historically has had a Malthusian policy limiting the growth of local surface areas for food sales. Restrictions were reinforced in 1996 and only partly removed in 2008. The policy was designed to shelter retailers in place from excessive competition. France has the strictest zoning rules in the OECD competitive database (Boylaud and Nicoletti, 2001). By contrast, and consistent with a deregulation-prone economy, entry is almost free in the USA.

As a result, large food retailing sales areas covered only 3.2 square feet per inhabitant in France ${ }^{5}$, compared to 5.5 square feet in the USA. ${ }^{6}$ This rate was even lower in the largest metropolitan areas. 
The problem was acute given a much larger food-at-home consumption market in France: in 2006, food-at-home spending per capita was $€ 2600$ in France in contrast to US\$1800 in the USA.

The combination of these temporal and physical shopping limitations on such a large market meant that French stores unavoidably experienced massive customer flows during peak hours. The two hypermarkets investigated welcomed 10,000 visitors on weekdays and 25,000 on Saturday.

French regulations promoted an organizational choice that maximized the number of cashiers and warranted an intensive (and stressful) organization of work for cashiers. In a hypermarket with a 100,000 -square-foot sales area, 50 cashier stations could operate simultaneously. Sitting reduced the space per cashier, allowing stores to maximize the number of cash registers. High scanning rates kept check-out lines flowing briskly. Nonetheless, French shoppers often experienced long waits during peak periods. This dramatically affected the relation between customers and cashiers: 'As soon as five or six people are standing in line, people suffer. They don't understand, they see us as robots and not as individuals. You always have to work faster' (hypermarket cashier).

More broadly, without barriers to entry, large US retailers faced sharp price competition heightened by the aggressive expansion of Wal-Mart and the adoption of its practices by other retailers.

Retailers' cost-cutting strategies increased downward pressure on wages. A supermarket chain HR VP in a low zoning regulation southeast US setting noted the impact of easy entry on their competitive environment: 'So that means it's that competitive and it means it keeps the prices down. Here you're constantly fighting for more customers so it's a very challenging environment to operate in.' In contrast, given barriers to entry in France, profits were simpler to extract. The pre-tax income of French supermarkets was 3.9 per cent of sales in 2005, almost twice that of US supermarkets $(1.9 \%$ for fiscal year 2006-7).

Societal effects with indirect impacts shape managerial practice: labour supply

The height of the wage floor and the length of store opening hours shaped retailers' labour preferences. Employers' demands were only half the story, however. A set of institutions and norms also shaped available labour supply. The meeting of labour demand and labour supply - each deeply influenced by institutions, regulation and managerial strategy - generated differing outcomes in cashier jobs.

The overall rate of part-time employment in retail in the USA grew over time from the 1950s onward, reaching its current level (28\% in 2007) by the end of the 1970s (Tilly, 1996: Table 2.5). Retrospective accounts single out the extension of store hours as a precipitating event. 'As hours started expanding ... you couldn't efficiently staff without part-timers, unless you wanted to have overlapping schedules and redundancies,' said the personnel director of a supermarket chain in the late 1980s (Tilly, 1996: 146). Part-time employment had two advantages for retailers. First, by intricate scheduling of parttime employees, stores were able to match staffing closely to demand, shedding 'excess' labour hours. A corollary was that US retailers particularly wanted a large mass of short hour, part-time jobs - with the option to adjust hours upwards. The second advantage was to achieve lower hourly pay and benefit savings. Management strategies thus drove the spread of part-time hours.

In France, on the other hand, retailers' labour demand was shaped by the high SMIC and the shorter store-opening hours. Some higher end supermarket operators signalled their conviction that their image required that their workers earn enough to buy in their stores. All of this drove retail employers to extract higher productivity. Concurrently, like US retailers, they aimed to have parttime workers available for added hours as needed, so they wished to deter employees from taking a second job. In addition, in their attempts to mirror a desired middle class clientele, French retail 
managers sought workers with more polished social skills and reportedly preferred white, nativeborn workers. In summary, their strategies led French retailers to design especially demanding jobs, which were filled selectively.

In both countries, the part-time workforce consisted overwhelmingly of young workers and women of all ages. Thus, as retailers boosted part-time employment, they reached out to women and young people. US labour market and welfare state institutions support the availability of these groups. US high school students generally have shorter school hours and years than their French counterparts about 799 instructional hours per year (Silva, 2007: Table 1) - leaving substantial afternoon and summer time available for work. In France, in contrast, the typical 15-year-old receives 1147 hours of instruction time per year (OECD, 2007: Table D1.1). It is also socially normal for a US high school student to work: 35 per cent of persons aged 16-19 were employed in the average month during 2007 (US Bureau of Labour Statistics, 2008a). In France, the norm is quite different, with only 9 per cent of 15-19-year-olds employed in 2006 (INSEE, 2008: T207). Persons aged less than 25, who make up 29 per cent of the US retail workforce, account for only 19 per cent in France.

It remains the norm in both countries that women are chiefly responsible for child care - but the institutional context differs dramatically. The USA lacks any national system of child care provision (Albelda, 2008), in contrast with France where almost half of two-year-olds and nearly all three-yearolds participate in a universal preschool system that extends to age six (Kamerman et al., 2003). A US supermarket cashier explained how, in the absence of subsidized care, child care impacted on her work availability: 'I work part-time. I can't work past one. That's the latest I work because then I go home with my daughter and my husband goes to work.' US law required only 12 weeks of unpaid maternity leave (and that only in the half of the workforce in larger businesses), quite different from France which required at least 16 weeks paid at the normal salary. These distinct institutional constellations meant there were a large number of female part-time job seekers available in the USA, with far fewer workers available in France. Indeed, in French retail in 2007, more than 61 per cent of the part-time young workers and 46 per cent of part-time women employees would have liked to work longer (INSEE, 2008).

A US retail job was seen as a 'good first job', as one manager put it. However, French earnings norms focussed on the monthly wage package, in contrast with the USA where, at least for supplementary earners, the hourly wage was most salient. Given this normative focus, French retailers that offerred low hourly wages in part-time jobs would be doubly cursed in the labour market, because low wages and short hours combined to give a much lower total monthly pay. Instead of a 'good first job', to French eyes, cashiering was often a job of last resort for the relevant populations.

Thus, in the USA, employers seeking low wage, part-time workers, including a large contingent of short hour workers, came face-to-face with students and mothers seeking part-time jobs, many of them accepting earning wages that supplemented other family income sources. The French story was quite different. The net effect was that as demand met supply, French retail employers sought more from their employees, even though the available French workforce was less disposed to work parttime jobs. Retailers were only able to square these two exigencies by offering an 'efficiency wage' (Akerlof and Yellen, 1986) designed to attract and retain desired employees and elicit ongoing effort. The alternative, as many managers pointed out, would be unmanageably high turnover, absenteeism and pursuit of second jobs that would limit the scheduling availability of part-time workers.

Importantly, not all French institutions had the effect that might be expected. French retail unions had won a minimum hours threshold of 26 hours. However, the policy was subject to exceptions for students and for those who 'voluntarily' choose to work fewer hours. In practice, case studies for this 
project and standard statistical sources found that the great majority of cashiers worked less than 26 hours. Nonetheless, extremely short hours were less common in France than in the USA. Whereas 18 per cent of US retail workers usually worked less than 15 hours per week, and 34 per cent less than 20 , in France, only 10 per cent and 16 per cent, respectively, did so. ${ }^{7}$

\section{Summary and conclusion}

This comparison of supermarket and hypermarket jobs in France and the USA does show some common sectoral features. In retail, regardless of the national model, managerial imperatives include tight control of costs, particularly labour cost, the need for flexible deployment of labour and the provision of adequate levels of service in the stores. Though some have characterized these features as a 'Wal-Mart effect' (Lichtenstein, 2009), in fact they long predate Wal-Mart's rise to US and international dominance.

But there are also differences. This combination of similarities and differences reflects distinct national-sectoral models in the two countries. Each national-sectoral model is formed by the interaction of national institutions and sector-specific characteristics (notably the need to staff stores during long and non-standard working hours), but not in an additive fashion. Rather, the particular institutions that matter for each national-sectoral model do so in ways that are conditioned by the particularities of the retail sector. With this study's focus on cashier jobs, the lowest paid category, labour regulation such as the minimum wage was quite important. Low wage jobs are those most likely to be protected by regulations that set a floor to the labour market (Gautié and Schmitt, 2010). Indeed, the higher minimum wage in France was found to play a significant role in accounting for the pay differential between the two countries. Higher compensation in France, in turn, underpinned a faster work pace.

Nevertheless, other aspects of job quality were not directly shaped by labour regulation but, rather, were affected by a cluster of other societal factors which, combined with product market regulations (restrictions on store hours and establishment of new stores), resulted in different employment practices and outcomes. Most importantly, given retail's reliance on part-time work, reproductive institutions shaping the labour force participation of mothers and youth loomed large. The effects of these other societal factors occurred primarily indirectly, affecting managerial practice, which in turn had repercussions on job characteristics. The iterative effects resulted in differences in pay, productivity and posture between the two countries.

A cautionary note is that this article has compared French and US retail jobs as if they were fixed, when in fact they are in flux. That flux reflects not just changing managerial strategies, but also changing institutions. Today's US retail jobs reflect a minimum wage that is low in historical terms, declining union density in retail and the demise of restrictions on store hours (Carré and Tilly, 2008). French retailers are currently pushing to liberalize store hours and reduce labour protection, and zoning policies are widely debated (Askenazy et al., 2008). This mutability in institutions, and thus societal effects, points to the need for further historical as well as comparative research.

This study's findings resonate with both the literature studying dominance effects on managerial practices and the literature on spheres of influence shaping job characteristics. Like studies in those streams of work, this study examines the complex interaction between society, firm and managerial practice, taking sector as a mediating influence on national effects. The existence of distinct nationalsectoral models points to the interdependent impact of societal and sectoral effects. The relevant societal effects in the case of retail are wide-ranging, embracing labour regulation via laws and collective bargaining, regulation of labour supply via schooling and care arrangements and regulation 
of product markets via laws restricting store hours and the opening of new stores, along with a normative overlay in each domain (e.g. a French norm that employees should be able to shop at the store where they work, norms about youth labour and expectations about when one should be able to shop). Arguably, societal effects remain strong because shopping culture and consumption patterns are deeply embedded in social life. Thus, despite the global dominance of a small number of giant retailers, societal effects are likely to remain strong in the retail sector.

\section{Acknowledgements}

This work was supported by the Russell Sage Foundation and the Gould Foundation for the Paris School of Economics. Special thanks to Chris Warhurst, Irena Grugulis, Phil Taylor and three anonymous reviewers for helpful comments. We also thank seminar audiences at the Paris School of Economics and the Massachusetts Institute of Technology.

\section{Notes}

1Gadrey (2000) offers a slightly different formulation though implications are similar.

2Smith and Meiksins's (1995) framework recognizing broad system effects (dynamics of capitalist production relations), societal effects and dominance effects brings similar dimensions to bear on, first, organizations' choices and, second, employment systems.

3Hypermarkets that were included in the French study sample were large and comparable to US supercenters.

4Authors' calculations from US Department of Labor (2008), US Bureau of Labor Statistics (2008b) and the Consumer Price Index for All Urban Consumers (CPI-U) index (US Bureau of Labor Statistics, 2008d).

5Including classic supermarkets, hard discount stores and hypermarkets. Figures for France in this subsection are estimated using Fédération du Commerce et de la Distribution (FCD, 2007) facts and INSEE (2008) databases.

6US figures in this sub-section come from the Food Marketing Institute's (2009) Supermarket Facts (2007 figures). A supermarket is any full-line self-service grocery store generating sales volume of US\$2m or more annually.

7US numbers (for 2007) computed from March 2007 Current Population Survey; French numbers (for 2006) from Esbjerg et al. (2010).

\section{References}

Akerlof GA, Yellen JL (eds) (1986) Efficiency Wage Models of the Labour Market. Cambridge: Cambridge University Press. Google Scholar Crossref

Albelda R (2008) Why it's harder (and different) for single mothers: gender, motherhood, labor markets and public work supports. Paper prepared for the Ford Foundation Economic Development 
Program, New York, NY, USA. Google Scholar

Askenazy P, Berry J-B, Prunier-Poulmaire S (2008) Working hard in French retailing. In: Caroli E, Gautié J (eds) Low Wage Work in France. New York, NY: Russell Sage Foundation, 209-53. Google Scholar

Baret C (2000) The organization of working time in large French food retail firms. In: Baret C, . (eds) Flexible Working in Food Retailing: A Comparison between France, Germany, the United Kingdom and Japan. London: Routledge, 31-57. Google Scholar

Baret C, Lehndorff S, Sparks L (eds) (2000) Flexible Working in Food Retailing: A Comparison between France, Germany, the United Kingdom and Japan. London: Routledge. Google Scholar

Bosch G, Lehndorff S (eds) (2005) Working in the Service Sector: A Tale from Different Worlds. London: Routledge. Google Scholar

Boylaud O, Nicoletti G (2001) Regulatory Reform in Retail Distribution. OECD Economic Studies 32: 254-72. Google Scholar

Carré F, Tilly C (2008) America's biggest low-wage industry: continuity and change in retail jobs. Paper produced for the Ford Foundation Economic Development Program, New York, NY, USA. Google Scholar

Carré F, Tilly C, Van Klaveren M, Voss-Dahm D (2010) Retail jobs in comparative perspective. In: Gautie J, Schmitt J (eds) Low-Wage Work in the Wealthy World. New York, NY: Russell Sage Foundation, 211-68. Google Scholar

Colling T, Clark I (2002) Looking for 'Americanness': home-country, sector and firm effects on employment systems in an engineering services company. European Journal of Industrial Relations 8(3): 301-24. Google Scholar Link

Dube A, Lester T, Reich M (2010) Minimum wage effects across state borders: estimates using contiguous counties. Review of Economics and Statistics 92(4): 945-64. Google Scholar Crossref

Esbjerg L, van Klaveren M, Voss-Dahm D (2010) Form follows function: part-time pattern in comparison. Unpublished manuscript, Aarhus School of Business, Aarhus, Denmark. Google Scholar

EU KLEMS (2008) Growth and Productivity Accounts. Available (consulted 25 June 2008) at: http://www.euklems.net Google Scholar

FCD (Fédération du Commerce et de la Distribution) (2007) Rapports de branche. Available (consulted 2 January 2009) at: http://www.fcd.asso.fr Google Scholar

FCD (Fédération du Commerce et de la Distribution) (2008) Rapports de branche. Available (consulted 2 January 2009) at: http://www.fcd.asso.fr Google Scholar

Ferner A (1997) Country of origin effects and HRM in multinational companies. Human Resource Management Journal 7(1):19-37. Google Scholar Crossref

Food Marketing Institute (2009) Supermarket Facts. Available (consulted 2 January 2009) at: http://fmi.org/facts_figs/?fuseaction=superfact Google Scholar 
Gadrey J (2000) Working time configurations: theory, methods and assumptions for an international comparison. In: Baret C, . (eds) Flexible Working in Food Retailing: A Comparison between France, Germany, the United Kingdom and Japan. London: Routledge, 21-30. Google Scholar

Gadrey J, Lehndorff S, Ribault T (2000) A societal interpretation of the differences and similarities in working time practices. In: Baret C, . (eds) Flexible Working in Food Retailing: A Comparison between France, Germany, the United Kingdom and Japan. London: Routledge, 143-67. Google Scholar

Gallie D (ed.) (2007) Employment Regimes and the Quality of Work. Oxford: Oxford University Press. Google Scholar Crossref

Gautié J, Schmitt J (eds) (2010) Low-Wage Work in the Wealthy World. New York, NY: Russell Sage Foundation. Google Scholar

Hall P, Soskice D (eds) (2001) Varieties of Capitalism: The Institutional Foundations of Comparative Advantage. New York, NY: Oxford University Press. Google Scholar Crossref

INSEE (Institut National de la Statistique et des Études Économiques) (2008) Labour Force Survey [LFS 2005-6] Available (consulted 25 June 2008) at:

http://www.insee.fr/fr/themes/detail.asp?ref_id=ir-

martra08\&reg_id=0\&page=irweb/MARTRA08/dd/martra08_paq2.htm Google Scholar

INSEE (Institut National de la Statistique et des Études Économiques) (2009a). Monthly Household Consumption of Goods. Available (consulted 5 January 2009) at:

http://www.bdm.insee.fr/bdm2/affichageSeries.action?idbank=001613500\&codeGroupe=1309 Google Scholar

INSEE (Institut National de la Statistique et des Études Économiques) (2009b) Le commerce en 2008. Rapport sur les comptes. [Coll. Comptes nationaux, Paris] Available (consulted 5 January 2009) at: http://www.insee.fr/fr/publications-et-services/docs_doc_travail/E0910.pdf Google Scholar

Jany-Catrice F, Lehndorff S (2005) Work organisation and the importance of labour markets in the European retail trade. In: Bosch G, Lehndorff S (eds) (2005) Working in the Service Sector: A Tale from Different Worlds. London: Routledge, 211-36. Google Scholar

Kamerman S, Neuman M, Waldfogel J, Brooks-Gunn J (2003) Social Policies, Family Tapes and Child Outcomes in Selected OECD Countries, OECD Social, Employment and Migration Working Papers, 6. Paris: OECD. Available (consulted 25 June 2008) at: http://www.oecd.org/dataoecd/26/46/2955844.pdf Google Scholar

Katz HC, Darbishire O (2000) Converging Divergences: Worldwide Changes in Employment Systems. Ithaca, NY: Cornell University Press. Google Scholar

Lehman KR, Psihogios JP, Meulenbroek RGJ (2001) The effects of sitting vs. standing and scanner type on cashiers. Ergonomics 44(7): 719-38. Google Scholar Crossref, Medline

Lichtenstein N (2009) The Retail Revolution: How Wal-Mart Created a Brave New World of Business. New York, NY: Metropolitan Books. Google Scholar

Maurice M, Sellier F, Silvestre J-J (1986) The Social Foundations of Industrial Power. Cambridge, MA: 
Meardi G, Marginson P, Fichter M, Frybes M, Stanojeveć M, Tóth A (2009) Varieties of multinationals: adapting employment practices in Central Eastern Europe. Industrial Relations 48(3): 489-511. Google Scholar

OECD (Organisation for Economic Cooperation and Development) (2007) Education at a Glance 2007. Paris: OECD. Available (consulted 25 June 2008) at:

http://www.oecd.org/document/30/0,3343,en_2825_495609_39251550_1_1_1_1,00.html\#toc Google Scholar

OECD (Organisation for Economic Cooperation and Development) (2008) Prices and Purchasing Power Parities. Available (consulted 25 June 2008) at:

http://www.oecd.org/topicstatsportal/0,3398,en_2825_495691_1_1_1_1_1,00.html\#500300 Google Scholar

Royle T (2006) The dominance effect? Multinational corporations in the Italian quick food service sector. British Journal of Industrial Relations 44(4): 757-59. Google Scholar Crossref

Silva E (2007) On the Clock: Rethinking the Way Schools Use Time. Washington, DC: Education Sector. Available (consulted 25 June 2008) at:

http://www.educationsector.org/usr_doc/OntheClock.pdf Google Scholar

Smith C, Meiksins P (1995) Systems, society and dominance effects in cross-national organizational analysis. Work, Employment and Society 9(2): 241-67. Google Scholar Link

Tilly C (1996) Half a Job: Bad and Good Part-Time Jobs in a Changing Labour Market. Philadelphia, PA: Temple University Press. Google Scholar

US Bureau of Labor Statistics (2008a) Labor Force Statistics from the Current Population Survey, Annual Averages. Available (consulted 24 June 2008) at: http://stats.bls.gov/cps/tables.htm\#annual Google Scholar

US Bureau of Labor Statistics (2008b) Current Employment Statistics. Available (consulted 24 June 2008) at: http://stats.bls.gov/ces Google Scholar

US Bureau of Labor Statistics (2008c) Current Population Survey [March 2007 survey] Available (consulted 3 May 2008) at: http://thedataweb.rm.census.gov/ftp/cps_ftp.html Google Scholar

US Bureau of Labor Statistics (2008d) Consumer Price Index. Available (consulted 24 June 2008) at: http://stats.bls.gov/cpi/data.htm Google Scholar

US Census Bureau (2005a) Product Lines: 2002. 2002 Economic Census, Retail Trade, Subject Series. Available (consulted 24 June 2008) at: http://www.census.gov/prod/ec02/ec0244slls.pdf Google Scholar

US Census Bureau (2005b) Miscellaneous Subjects: 2002. 2002 Economic Census, Retail Trade, Subject Series. Available (consulted 24 June 2008) at: http://www.census.gov/prod/ec02/ec0244sxsb.pdf Google Scholar

US Census Bureau (2008a) County Business Patterns 2006. Available (consulted 24 June 2008) at: 
http://www.census.gov/epcd/cbp/index.html Google Scholar

US Census Bureau (2008b) Annual Retail Trade Survey 2006. Available (consulted 24 June 2008) at: http://www.census.gov/svsd/www/artstbl.html Google Scholar

US Department of Labor (2008) History of Federal Minimum Wage Rates under the Fair Labour Standards Act. Available (consulted 23 October 2008) at:

http://www.dol.gov/esa/minwage/chart.htm Google Scholar

US Federal Reserve Board (2009) Foreign Exchange Rates (Annual). Available (consulted 2 February 2009) at: http://www.federalreserve.gov/releases/g5a/current/ Google Scholar

Whitley R (1999) Divergent Capitalisms: The Social Structuring and Change of Business Systems.

Oxford: Oxford University Press. Google Scholar 